\title{
AN ANALYSIS OF THE ELECTRICAL BURST PHENOMENON IN SOME RHINENCEPHALIC STRUCTURES OF THE DOG AND MONKEY ${ }^{1}$
}

\author{
Edward F. Domino, M.D. and Showa UEKI, M.D.2 \\ Department of Pharmacology, University of Michigan, Ann Arbor
}

(Received for publication: September 19, 1959)

During a study of the actions of various drugs on the cerebral electrical activity of dogs and monkeys with chronic electrode implants, it was noted that especially during behavioral and EEG arousal electrical bursts of approximately $40 \mathrm{e} / \mathrm{sec}$. were present in certain rhinencephalic structures including the medial amygdala, olfactory bulb, and posterior hypothalamus. Such a burst phenomenon has been observed previously by other investigators. Adrian (1942) was one of the first to describe groups of potentials of 15 to $20 \mathrm{c} / \mathrm{sec}$. in certain olfactory structures of the hedgehog under pentobarbital anesthesia. These electrical bursts oceurred primarily at each inspiration. During the intervening period there were occasional waves at irregular intervals or complete inactivity. The bursts were sinusoidal in character with a definite ascending phase reaching a maximum and gradually diminishing in amplitude. They were abolished by occlusion of the ipsilateral nostril and enhanced by occlusion of the contralateral nostril. With slow, shallow breathing there was some increase in the irregular waves during inspiration but no regular respiratory bursts. With deeper breathing the clectrical waves had a frequency of 15 to 25 $\mathrm{c} / \mathrm{sec}$. depending upon the level of pentobarbital anesthesia. When air was blown or sucked forcibly through the ipsilateral nostril the frequency increased to 35 to $45 \mathrm{c} /$ sec. In 1950, Adrian deseribed a similar phenomenon in rabbits anesthetized with urethane. Regular sinusoidal rhythms with a constant frequency of $50 \mathrm{e} / \mathrm{sec}$. were observed in this -...-

1 This study was supported in part by grant MY-2653, USPHS.

2 Present address: Department of Pharmacology, Tniversity of Kyushu, Faculty of Medicine, Fukuoka, Japar. species that were usually synchronous with inspiration. These sinusoidal rhythms were regarded by Adrian as a sign of synchronous excitation of large numbers of mitral cells of the olfactory bulb. The excitation of these cells was thought to be due to impulses from the olfactory receptors. Roitbak and Khechinashuili (1952) disagreed with Adrian as to the origin of the $50 \mathrm{c}$ see. rhythm synchronous with respiration. These investigators showed that the $50 \mathrm{c} / \mathrm{sec}$. rhythm in the olfactory bulb also occurred during deep inspiration in normal unanesthetized rabbits but they felt that the responses were due to mechanical vibration of the nasal bones. $\mathrm{N}_{0}$ vikova and Khvoles (1953) rejected this interpretation. These workers presented compelling evidence that the electrical bursts $\mathrm{re}^{-}$ corded not only in the olfartory bulb but also in portions of the hypothalamic system of rabbits were of a physiological nature and related to the passage of air through the nose. If the electrical discharges recorded in tho olfactory bulb were due to a mechanical vibration then one wonld expest air flow throngh the nasal cavity of a dead animal to produce similar phenomena. Tnder these circumstanees no bursts of impulses were observed in the olfactory bulb. MacLean and Delgado (1953) described similar rhythmic activity in the amyodala of monkeys that was synchronous with respiration. These investigators wore mable to localize the rhythmic burst diseharge to any partieular part of the amygdala. The potentials appeared to be more rhythmie than in the cat. In monkeys nuder amobarbital anesthesia the electrical bursts had a frequency of $26 \mathrm{c} /$ sec. and occurred in spindles. These disappeared when the nasal passages were occluded or when a tracheal cannula was inserted. On the other hand, 
they were not modified by bilateral section of the vagus nerves. Very recently Lavin et al. (1959) observed during arousal electrical bursts in the olfactory bulb of cats with chronically implanted electrodes. They suggested that this phenomenon parallels EEG arousal. Although the electrical bursts appeared at approximately the same rate as respiration there was a dissociation at times between respiration and the electrical bursts in the olfactory bulb. Therefore, these investigators felt that the burst phenomena represented a centrifugal input into the olfactory bulb from the brain stem reticular formation as a result of EEG arousal.

It appeared that further information was needed on the conditions which modified the rhythmic electrical bursts in various rhinmucephalic structures. The purpose of the present paper is to describe how various merhanical procedures and pharmacological agents modify the burst responses in dogs and monkeys with chronice electrode implants.

\section{METIIODS}

Monlicys. Six Macaca mulatta monkeys of both sexes wrighing from 2 to $4 \mathrm{~kg}$. were used. These were suceessfully implanted (hronically with 12 pairs of bipolar electrodes in varions portions of the brain, both rortically and subcortically. The animals were operated upon under pentobarbital anesthesia. Twisted bipolar \# 32 gauge stainless steel wire, Formex coated, was used for the recording electrodes. For additional insulation the twisted wires were coated with Epoxylite or K-13 Tygon paint thinned with Tygon thinner TP-91. At least 2 to 3 coats of insulation were applied. Following each application the insulated electrodes were baked in an electric uven at $70^{\circ}$ (c. for 2 to 4 hours. The electrode tips, separated 2 to $3 \mathrm{~mm}$., consisted of small hare balls of approximately $15 \mathrm{mils}$ in diameter. These balls were made by melting the and of the wire using a modification of the method of Riley (1949) for welding thermocomples. In series with the mercury-mineral oil well was placed a 75,100 , or 150 watt electrie light bulb. Instead of a direct current a $110 \mathrm{~V} .60$ eycle alternating enrent was used. By varying the wattage of the electric light bulb, different ball sizes could be obtained by dipping the electrode into the mineral oil and making and breaking contact with the mercury layer. After fixation of the monkey's head in a Lab Tronics stereotaxic instrument, small (3 $\mathrm{mm}$.) burr holes were placed into the skull at the desired sites. Cortical electrodes were placed either epi- or subdurally. Subsequently it was noted upon autopsy that frequently the subdural cortical electrodes pierced the pia mater and produced definite lesions. Because of these diffientties the cortical electrodes were subsequently placed epidurally. Eleetrodes were implanted in subeortical sites by insertingr one of the alectrode balls into the end of a slit in an evenly polished \# 20 spinal needle approximately 6 inches long. The clectrodes were drawn up tight and parallel to the needle shaft with a ligature. By inserting the plunger into the spinal needle it was possible to dislodge the stainless steel ball at its end. The needle could then be withdrawn by carefully holding the implanted wire electrod in place. The clectrodes were fixed to the alvarium by filling the burr holes with a dental acrylie. plastic (Yates; Nu-Set).

A modification of the Sheatz and Galambos tripod plate ("Texas Tower" was used to hold a Camnon plug (DA or DB series) of 15) or 25 eontacts. All electrode connections. were soldered using a stainless steel flux. Any excess of flux was subsequently washed off with 0.9 per cent saline. The tripod assembly was attached to the calvarium by means of a kevhole arrangement and the feet of the tripod were tightened in place with stainless steel nuts. Dental acrylice plastic was used to fill in the holes in the calvarium as well as below the entire assembly to prevent the animal from picking at the alectrodes, as well as to insure adequate insulation. The stereotaxic coordinates for the sites of electrode placement were determined using the atlas by Oleszewski (1952). After surgery the animals were given 400,000 mits of penicillin intramuscularly, arch day for + dass. Inferetion was minimum. The animals tolerated the electrode implants very well. Some ehronie 
local infection occasionally persisted at the skin edges. If the chronic local infection became severe the animals tended to lose their electrode implants within 6 months after sururery. Some animals retained their chronic electrode implants for as long as one and a half years.

Dogs. Seven male dogs including 3 pure bred beagle and 4 beagle-like mongrels were successfully implanted with 12 pairs of bipolar electrodes both cortically and subcortically. The animals were operated upon under pentobarbital anesthesia, and prepared in a manner similar to that described for monkeys. A "Texas Tower" electrode plate was used, but with longer feet. After fixation of the dog's skull in a modified head holder for the Lab 'Tronics stereotaxic instrument small burr holes were placed into the skull at the desired sites. The stereotaxic coordinates for the sites of the electrode placement were determined from previous histological studies of several pure bred beagles and beagle-like mongrels. $\Lambda$ fter surwery the animals were given 400,000 units of penicillin intramuseularly each day for 4 days. Generally infection was minimal. However, this procedure was not as well tolerated as in the monkeys. Frequently the dogs developed within 6 months rather severe infections of the scalp and calvarium, and subsequently lost their electrode implants. Therefore, an attempt was made to use the dogs as soon as possible following surgery. However, it was found that usually about a month period of convalescence was necessary for adequate postoperative recovery.

Both the dogs and monkeys were placed in a closed compartment with a one-way window for observation. All recordings were made with the unanesthetized monkeys restrained in a "Walter Reed" type plastic chair. The dogs wore appropriately restrained in a stockade during electrical recordings. A Model III Grass electroencephalograph was used. Thoracie respiration was monitored by means of a rubber bellows connected to a Statham P23 transducer and Grass balance-demodulator on one rhannel of the electroencephalograph. Whenever possible, the brain sites were confirmed histologically by the Hess iron deposi- tion technique and stained with the prussian blue and/or green color at the electrode tips. The nerve cells were counterstained with thionin (see Domino 1955, for details).

\section{RESLLTS}

\section{Electrical Burst Phenomenon in Monkeys.}

Although electrical bursts of approximately $40 \mathrm{c} / \mathrm{sec}$. were observed in monkeys when they were asleep, characteristically these bursts were most clearly evident when the animals were aroused. Various afferent stimuli were capable of enhancing the bursts in the medial amygdala, prepyriform, pyriform cortex, or olfactory striae. It seemed that the important factor was the degree of arousal. The more excited the monkey, the more likely bursts were observed. Generally the bursts were synchronous with inspiration. These offects were quite consistent and were observed in at least 5 implanted monkeys. As son in panel $A$, figure 1 , the amygdala bursts were especially evident during EEG arousal. The monkeys were in a quiet environment and would easily doze in the restraining chair. Periodically with spontaneous aromsal as illustrated in this figure the characteristic high voltage, slow wave activity present in nocortical structures changed to a low voltage, fast frequency pattern. At the same time bursts of $40 \mathrm{c} / \mathrm{sec}$. were observed every few seeonds in the amyodala or related olfactory areas. When the animal began to sleep high voltage activity again appeared in the neocortical structures and the bursts in the anygdala became less evident. After lour noises, as shown in the EEG record of panel B, figure 1, the bursts again appeared in the amygdala and were accompanied by a low voltage, fast frequency EEG in the neocortical areas. Painful stimuli were particularly effective in eliciting the burst phenomenon. Stimulation of the tooth pulp at slightly above threshold caused very clear high frequency poriodic discharges in the amyodala as shown in the EEG record of panel $\mathrm{C}$, figure 1. Pain induced by increasing the pressure in a balloon inserted into the rectum similarly caused high frequency periodic bursts in the amygdala (panel D, figure 1). Following rectal disten- 
tion not all neocortical structures showed a low voltage, fast frequency EEG pattern. Particularly after continuous rectal distention the more frontal portions of the neocortex showed high voltage delta waves at a time when the monkey was extremely uncomfortable and agritated. On the other hand, especially the that the high frequency bursts were related to the passage of air through the nostrils.

To study this phenomenon further a rubber bellows was strapped around the chest of the monkey in order to measure thoracic respiration. In awake monkeys the amygdala bursts ocenred periodieally and were at a

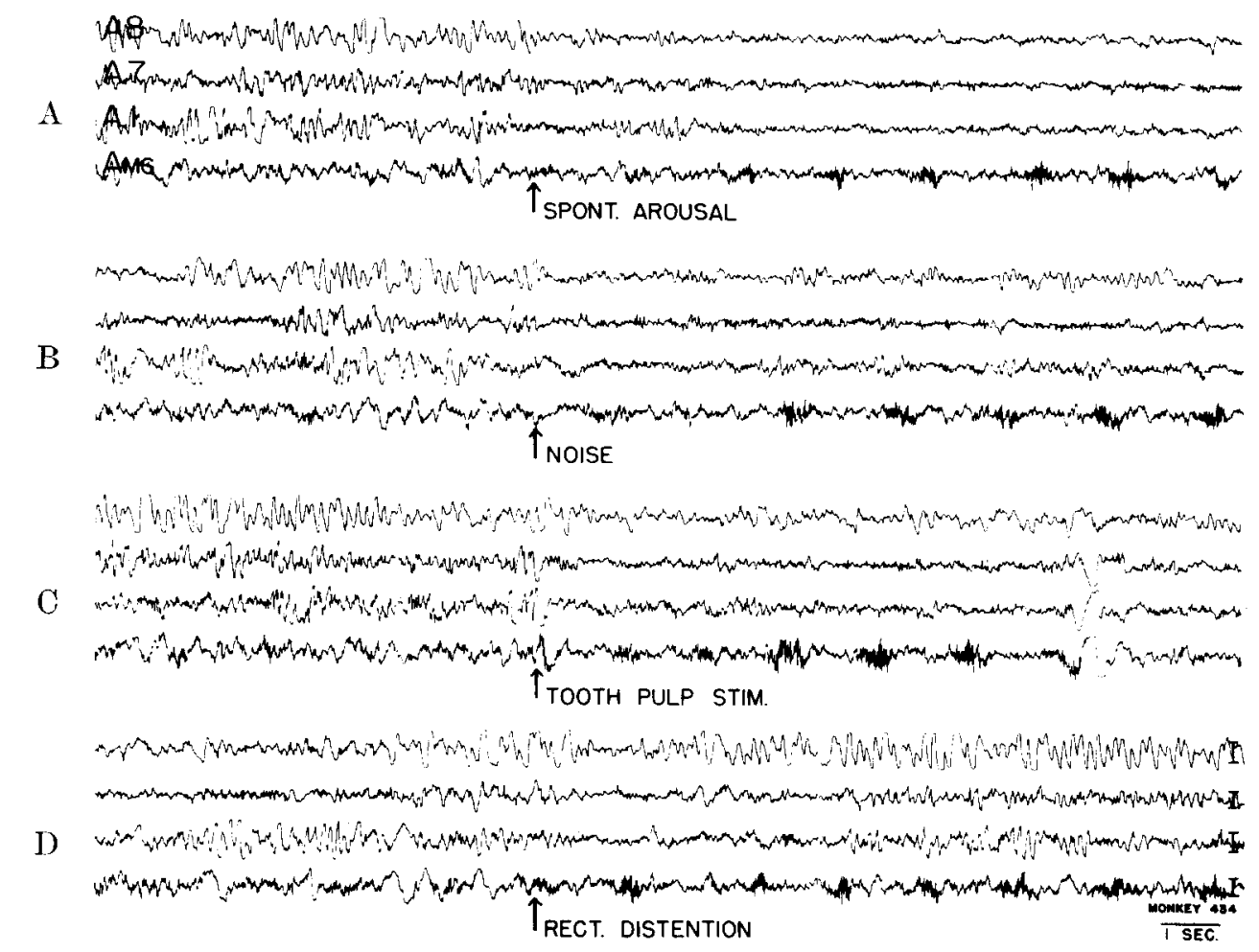

Fig. 1

Amygdala bursts in the monkey following a rousal due to virious afferent stimuli.

Panel A - Spontaneous behavioral and EEG arousal. Panel B - Behavioral and EEG arousal to a loud noise. Panel $\mathrm{C}$ - Behavioral and EEG arousal to stimulation of the tooth pulp. The left canine tooth was prepared 1 month previously with bipolar clectrodes for stimulation of the tooth pulp. Parameters of stimulation were $5 \mathrm{~V} .30 \mathrm{c} / \mathrm{sec}$., pulse width 1 insec. for 3 see. Panel D - Behavioral and partial EEG arousal to rectal distension by means of a rubber balloon inserted into the rectum. The balloon was distended to $20 \mathrm{~mm}$. mean mereury pressure. Bipolar electrical recordings were taken throughout. Svmbols are: A8 - cortical area 8; A7 - cortical area $7 ; A 1$ - cortical area $1 ; A M C$ merlial amygdala. Voltage calibration - 100 microvolts.

more posterior and parietal areas showed low roltage, fast frequency activity at this time.

Frequently, the high frequeney bursts were synchronous with respiration. In addition to the depth of respiration the presence or absence of bursts in various rhinencephalic structures depended upon whether the animal was breathing through its mouth. It appeared maximum during inspiration. These effects are illustrated in a portion of the EEG record in figure 2. As can be seen in panel $A$, the high frequency amygdala bursts occurred maximally during inspiration. Occlusion of the mouth and contralateral nostril enhanced the amplitude and duration of the amygdala bursts (see panel $\Lambda$, fig. 2). On the other 
hand, occlusion of the mouth and ipsilateral nostril completely abolished burst activity (see panel B, fig. 2). Occlusion of the ipsilateral nostril alone likewise was sufficient to abolish the burst phenomenon. If room air was blown into the ipsilateral nostril particularly upward toward the cribiform plate the electrical bursts could be produced that were very similar to those occurring spontaneously with normal respiration. A record of this is illustrated in panel $\mathrm{C}$, figure 2. At the arrows a small amount of air, ap- bursts by spraying the ipsilateral nostril with a local anesthetic solution. On the other hand, spraying the contralateral nostril should not affect appreciably burst phenomenon on the ipsilateral side. This hypothesis was confirmed by 10 experiments in 5 monkeys. A representative record of the effect of lidocaine is shown in figure 3. In pancl A are illustrated the normal amygdala bursts synchronous with inspiration. In order to enhance the electrical bursts in this particular monkey a small amount of rotton wadding

A
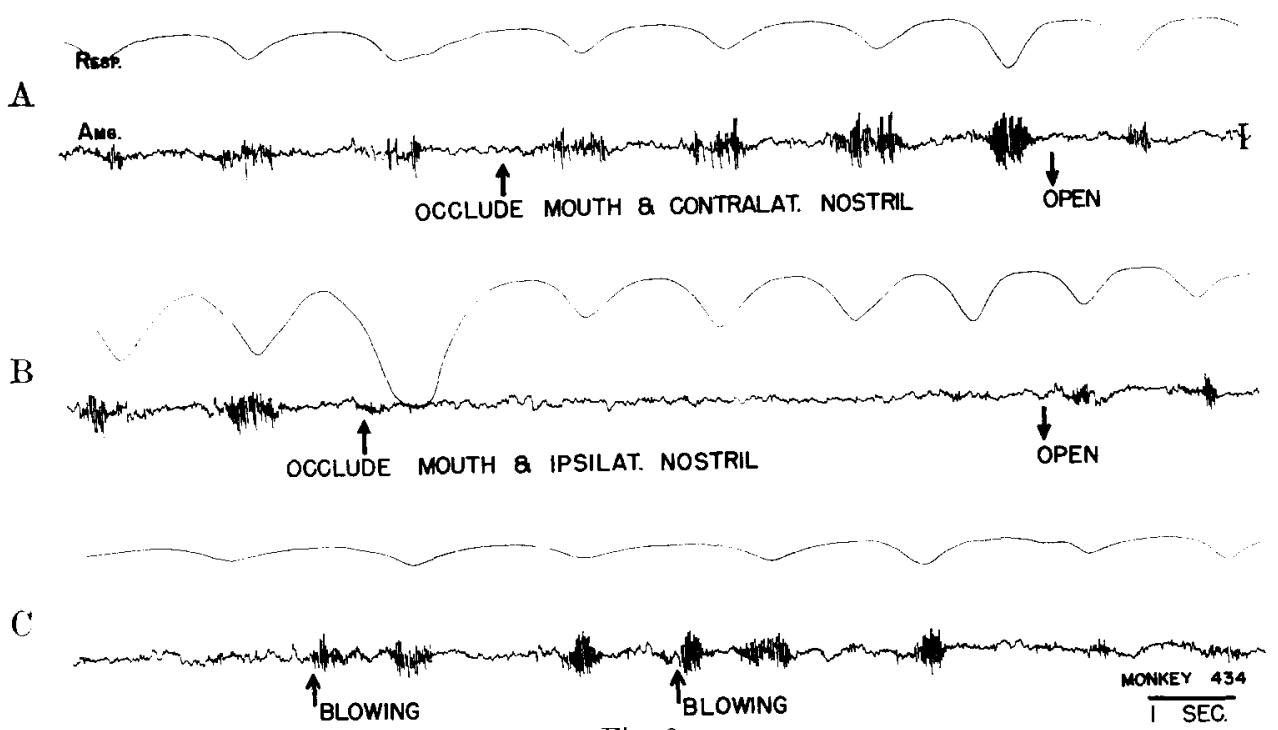

Fig. 2

Effects of nasal oeclusion on the electrical activity of amygdala of the monkey.

Panel A - Effects of occlusion of the mouth and contralateral nostril on amygdala bursts. The block was applied at the upward arrow and relieved at the downward arrow. Panel $\mathrm{B}$ Effects of occlusion of the mouth and ipsilateral nostril on amygdala bursts. The block was applied at the upward arrow and relieved at the downward arrow. Panel C - Effects of blowing room air (at the arrows) through the ipsilateral nostril on the electrical activity of the amygdala. Symbols are: RESP. - thoracie respiration. Inspiration is downwart. AMG. - medial amygdala. Voltage calibration -- $100 \mu \mathrm{V}$.

proximately $5 \mathrm{ml}$. was blown rapidly into the ipsilateral nostril. Under these circumstances bursts of $40 \mathrm{c} / \mathrm{sec}$. were produced that were similar to those occurring with normal respiration.

The above results suggested that the electrical bursts recorded periodically in the amygdala and other olfactory structures of the monkey were related to a flow of air through the ipsilateral nostril, and therefore were of afferent origin. If this were so it should be possible to abolish the electrical was inserted into the contralateral nostril and the mouth occluded. Under these eircumstances the animal was only able to breathe through the ipsilateral nostril and the amygdala bursts recorded on that side were especially marked. Blowing approximately $5 \mathrm{ml}$. of room air into the ipsilateral nostril easily reproduced the electrical bursts in the amygdala as illustrated at the arrow in the right hand record of panel $A$. One minute after the intranasal application of $0.5 \mathrm{ml}$. of 2 per cent lidocaine in a saline solution the electrical 
bursts recorded in the amygdala were practically abolished. Similarly, blowing room air into the ipsilateral nostril was relatively ineffective in producing the normal electrical bursts in the amygdala. About 1 hour after the intranasal application of lidocaine the electrical bursts gradually became more noticeable. $A s$ illustrated in the record of panel $\mathrm{C}$, the bursts were diminished but evident. Blowing room air into the ipsilateral nostril produced a definite though attenuated electrical dis- (hronic electrode implants. The bursts were from 40 to $46 \mathrm{c} / \mathrm{sec}$. in the olfactory bulb. In the dog these oceurred not only during inspiration, but also were seen during expiration. Curiously, the frequency of the eleetrical bursts recorded in the ipsilateral amygdala frequently was precisely half that in the olfactory bulb. Generally, the frequency of the amygdala bursts varied from 20 to $2: 3$ c/sec. depending upon the dog studied. In figure 4 , panel $A$, is illustrated the normal
A

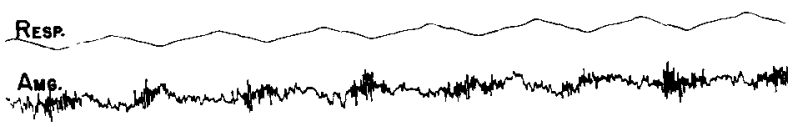

B

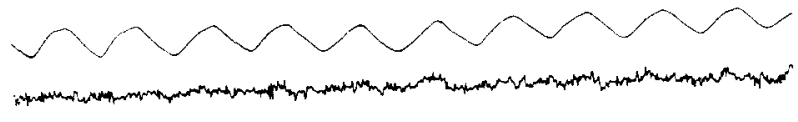

C

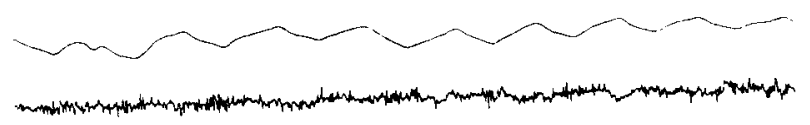

$\mathrm{D}$

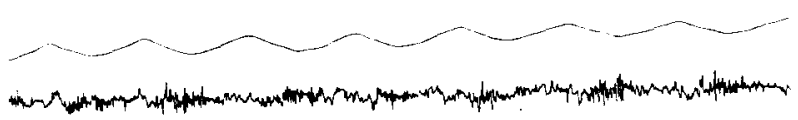

Fig. 3
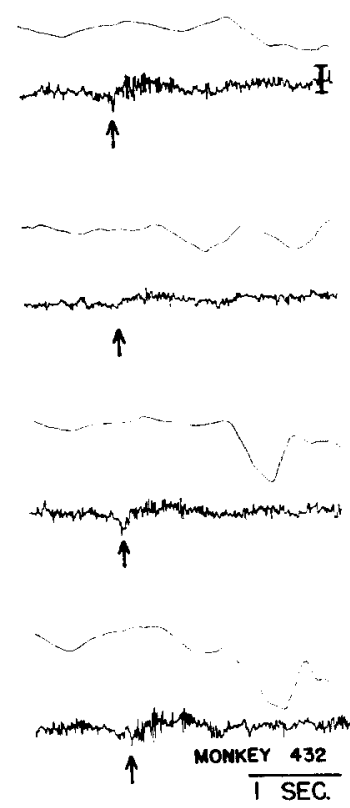

Effects of intranasal lidocaine on the electrical aetivity of the amygdala in the monkey.

Panel A - Normal respiration. Approximately $5 \mathrm{ml}$. of room air was blown into the ipsilateral nostril at the arrow. Panel B - One min. after the ipsilateral intranasal injection of $0.5 \mathrm{ml}$. of 2 per cent lidocaine. Panel C - Sixty-seven min. after the intranasial administration of lidocaine. Panel D - Approximately 95 min, after the intranasal administration of lidocaine. Some recovery of the burst phenomena is observed. Symbols and voltage calibration are similar to those in previous figures. Throughout the entire experiment the mouth and contralateral nostril were occluded by means of a cotton ball and adhesive tape.

charge. About $1 \frac{1}{2}$ to 2 hours after the intranasal administration of lidocaine the electrical bursts in the medial amygdala returned toward control levels. Similarly at this time blowing room air into the ipsilateral nostril was effective again in producing normal burst activity (see panel $\mathbf{D}$, fig. 3 ).

\section{Electrical Burst Phenomenon in Dogs.}

The electrical bursts synchronous with respiration were especially obvious in dogs with electrical activity of the amygdala and olfactory bulb of a dog who is awake. This particular animal alternated between panting and normal respiration. Although the electrical bursts in the olfactory bulb were clearly evident those in the amygdala were not obvious. However, by occlusion of the mouth and contralateral nostril the amygdala bursts became clearly evident as illustrated in panels $B$ and $D$, figure 4 . On the other hand, occlusion of the ipsilateral nostril and 
the mouth almost completely abolished the electrical bursts, both in the olfactory bulb and in the amygdala (see panel $\mathrm{C}$, fig. 4). The electrical bursts in the olfactory bulb frequent and usually the most prominent were electrical bursts at 40 to $46 \mathrm{c} / \mathrm{sec}$. However. every second spike was enhanced and oceurred at a frequency of 20 to $23 \mathrm{a} / \mathrm{sec}$. These cor-

A

Anempry

And

$\mathrm{OB}$

SB

B

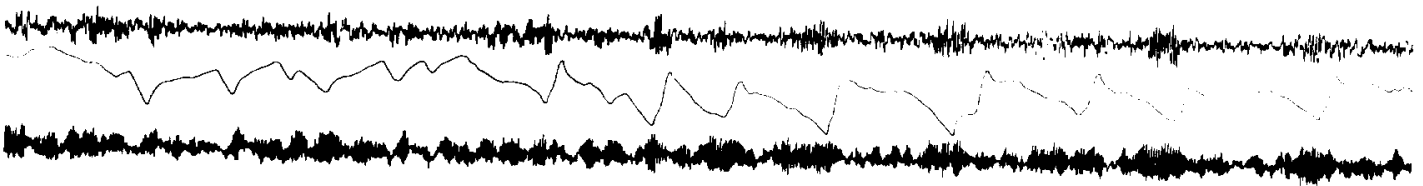

C

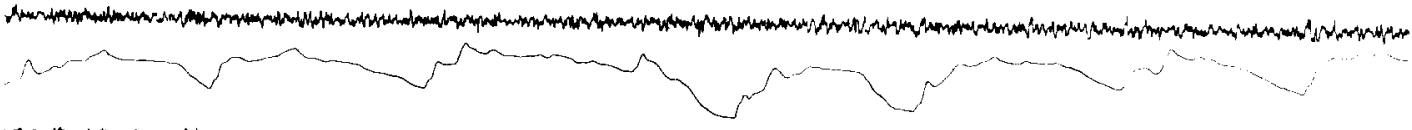

$\mathrm{D}$

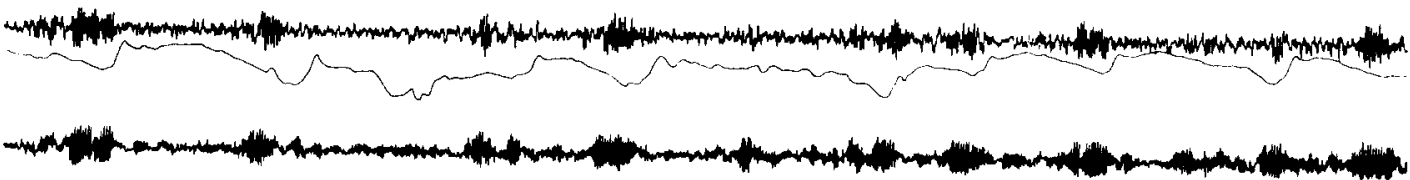

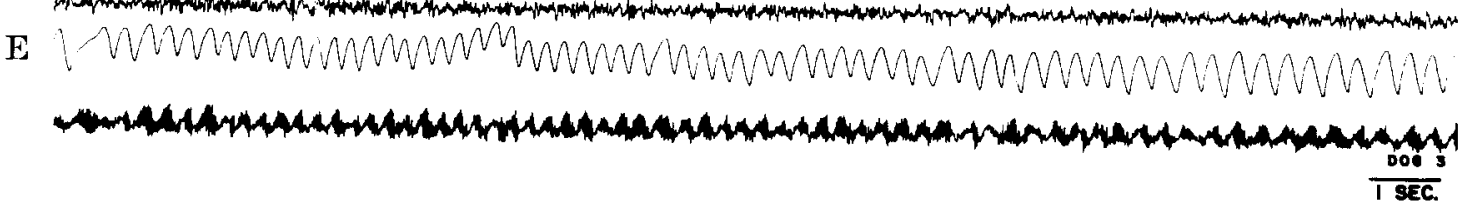

Fig. 4

Effects of nasal ocelusion on the electrical activity of the olfactory bulb and modial amygdala of the dog.

Panel A - Electrical activity recorded in the olfactory bulb and amygdala of a normal dog. The mouth and both nostrils were open. Panel B - The mouth and contralateral nostril were oceluded throughout the period illustrated. Panel - The mouth and ipsilateral nostril were occluded during the period illustrated. Panel D - Repeat of $B$. The mouth and contralateral nostril were occluded during the period illustrated. Panel E - Repeat of A. Normal panting respiration with mouth and nostrils open. The symbols and voltage calibration are similar to those of previous figures.

and amygdala could be abolished or enhanced by occlusion of either the ipsilateral or contralateral nostril. It is especially clear in panel $\mathrm{D}$, figure 4 that there were two types of potentials in the olfactory bulb. The most related precisely with the frequency of the bursts in the amygdala. If the mouth and both nostrils were again opened the electrical bursts recorded in the olfactory bulb were similar to those of control. In this particular 
animal normally minimal burst activity was present in the amygdala (panels $\mathbf{A}$ and $\mathbf{E}$, fig. 4). However, most of the dogs showed clear "ut responses in the amygdala normally.

The relative ease with which the electrical bursts were recorded in the olfactory bulb and amygdala of dogs suggested that this species rould be used in studying the effects of various stimulant and sedative drugs which modify the state of arousal.

\section{Effects of d-Amphetamine.}

The effects of d-amphetamine on the electrical activity of neocortical and rhinencephalic structures was determined in 5 dogs. In all animals the effects were quite similar. (l-Amphetamine was given in a dose of $\mathbf{1 . 0}$ $\mathrm{mg} / \mathrm{kg}$., intravenously. In panel $\mathrm{A}$, figure 5 , is illustrated the control EEG activity of a normal animal with a chronic electrode implant. The neocortical areas showed the characteristic low voltage, fast frequency pattern of an awake dog. Two bipolar recording electrodes were in different portions of the olfactory bulb of this animal. In general, electrical bursts were seen synchronous with respiration. The dog alternated between normal respiration and episodes of panting. Within 5 min. after the intravenous administration of $1.0 \mathrm{mg} / \mathrm{kg}$. of d-amphetamine the dog showed considerable gross agitation and nervousness. Thromghout this time the EEG continued to show a low voltage fast frequency pattern in the neocortical structures. As illustrated in panel $B$, figure 5 , the electrical activity of the olfactory bulb of this animal as well as that of the amygdala and related olfactory structures in other dogs showed a marked enhaneement in the amplitude of the electrical bursts synchronous with respiration. Occlusion of the contralateral nostril, if anything, slightly enhanced the amplitude of these electrical bursts. On the other hand, ocolnsion of the ipsilateral nostril completely blocked the alectrical bursts. These were promptly restored upon opening the ipsilateral nostril. As seen in the record of panel $\mathrm{C}$, figure 5 , the amplitude of the electrical bursts in the olfactory bulb of this dog continued to be markedly enhanced even during panting respiration. On the other hand, the neocortical structures continued to show the characteristic low voltage, fast frequency pattern. These effects continued for approximately 1 to 2 hours and gradually diminished as the overt stimulation of d-amphetamine decreased.

\section{EEG Effects of Trans--orocamphor.}

Trans- $\pi$-oxocamphor (Vitacamphor) is a short acting respiratory stimulant. It was therefore of interest to determine the effects of this agent on the electrical burst phenomenom in the olfactory structures of the dog. A total of 5 animals were studied. The iffects observed were similar to those obtained with damphetamine but were more striking. Following $5 \mathrm{mg} / \mathrm{kg}$. of trans- $\pi$-oxocamphor given intravenously the electrical bursts were particularly marked and clearly evident in the amygdala and olfactory bulb. The duration of action of trans-m-oxocamphor to increase respiration was relatively short, lasting no more than 5 to 10 min. Within 3 min. after the intravenous injection of trans- $\pi$-oxoramphor the electrical bursts in the olfactory bulb and amygdala were alrealy slightly tecereased. Oeclusion of the ipsilateral nostril completely obliterated the electrical bursts. These were promptly restored when the ipsilatemal nostril was opened. Throughout the entire duration of action of trans- $\pi-0 x$ ocamphor the electrical activity of neocortical structures remained essentially the same.

\section{EEG Effects of llorphine.}

The effects of morphine sulfate were determined in 7 different dogs. In greneral, the gross behavioral and EE( phenomena observed paralleled one another. Following the administration of $1.0 \mathrm{mg} / \mathrm{kg}$. of morphine sulfate given intravenomsly the animals appeared less agitated. They showed some motor weakness, especially of the hindquarters. The animals frequently had to be supporied in the restraining apparatus. (Other well known signs of morphine intoxication were present inclnding marked salivation, defecation, and oreasional emesis. These effects appeared to become maximal in approximately $15 \mathrm{~min}$. At the height of these actions of morphine the EEG showed generalized slow waves in both neocortical and subeortical structures. The 


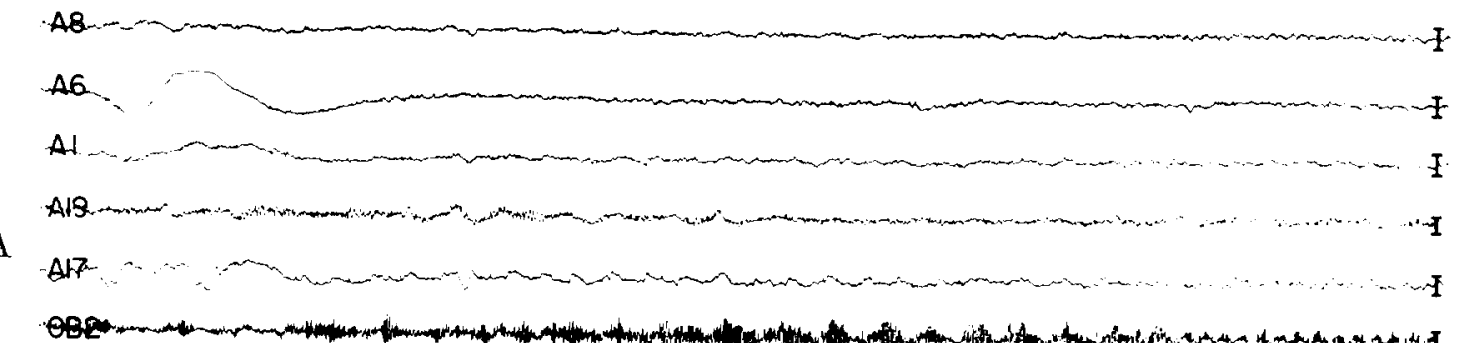

REse.

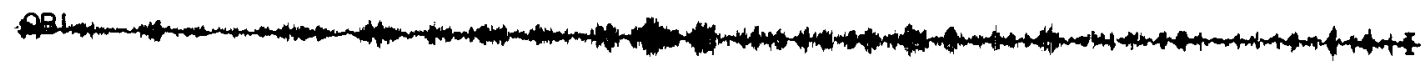

$\mathrm{B}$
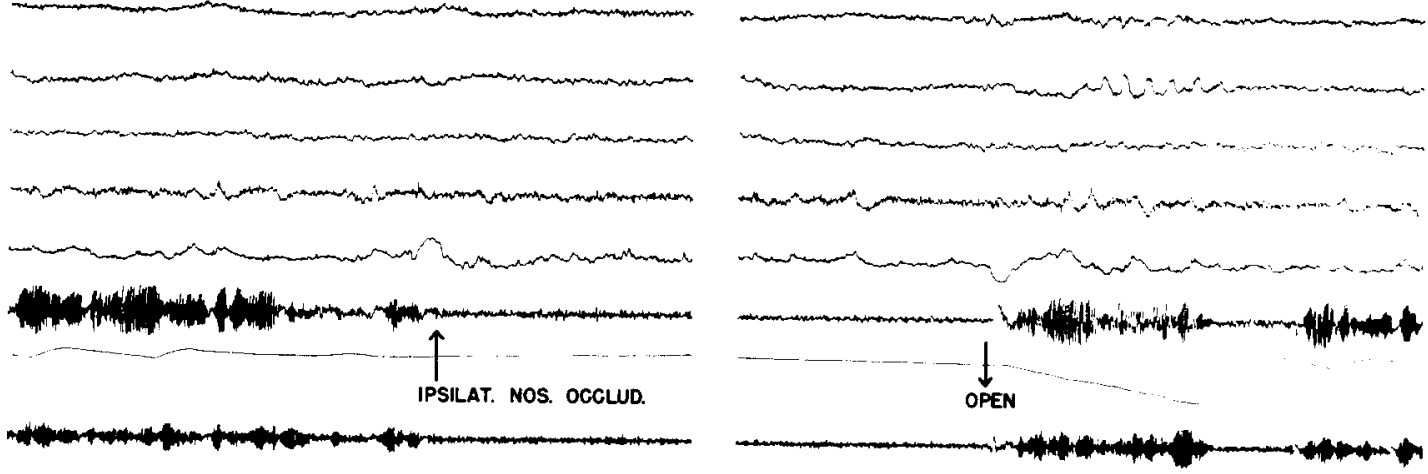

Prow

C

(1)

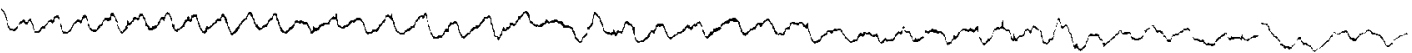

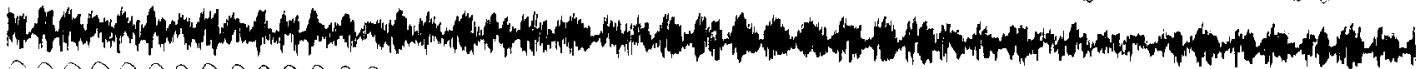

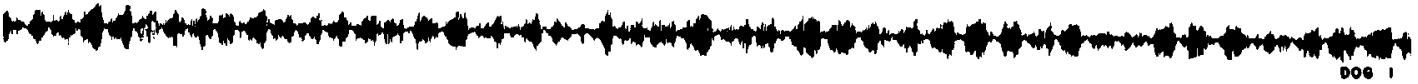

Fig. 5

EEG effects of d-amphetamine in the dog.

Panel A - Control EEG of an awake dog. Panel B - Twenty-two min. after $1.0 \mathrm{mg} / \mathrm{kg}$. of d-amphetamine given intravenously. A 10 sec. interval of the record between the left and right hand panels was removed. At the upward arrow the ipsilateral nostril was occluded and opened at the downward arrow. Panel C - Thirty-seven min. after the intravenous administration of d-amphetamine. Symbols and voltage ealibration are similar to those of previous figures except: A6 - cortical area $6 ; \mathrm{A} 19$ - cortical area $19 ; \mathrm{A} 17$ cortical area 17; OB2 - posterior olfactory bulb; $\mathrm{OB} 1$ - anterior olfactory bulb. 


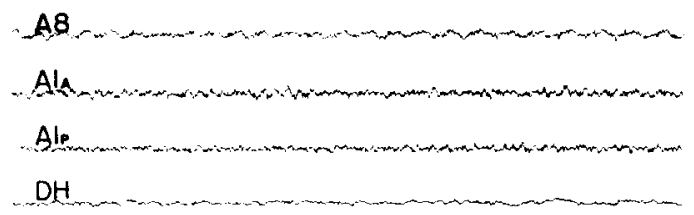

A

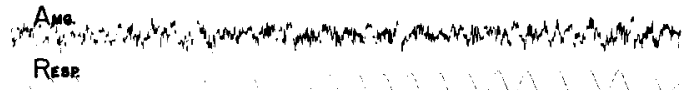

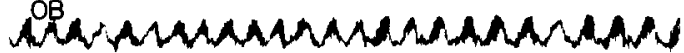

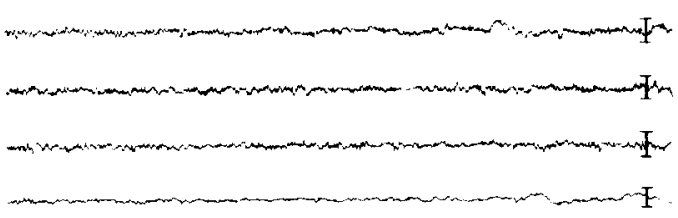

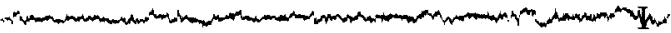

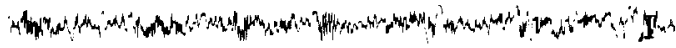
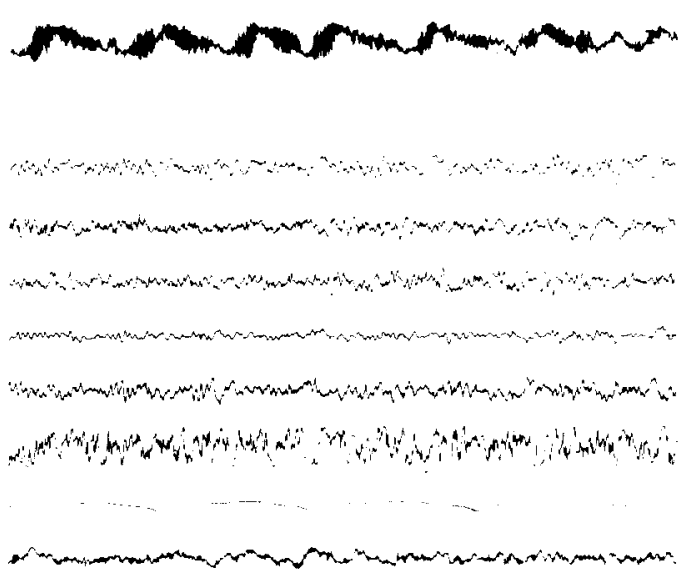

\section{.}

C

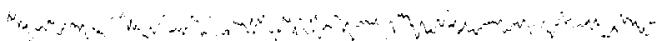

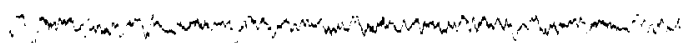

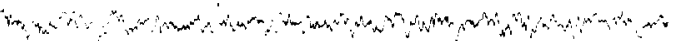

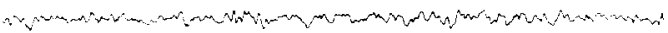

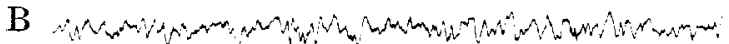

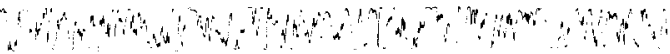

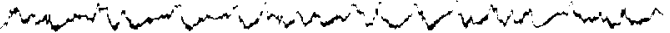


effects were promptly reversed by n-allylnormorphine (Nalline) in a dose of $1.0 \mathrm{mg} / \mathrm{kg}$. given intravenously. These effects on the EEG are shown in the record of figure 6 . In panel $A$, figure 6 is illustrated the normal control EEG of an unanesthetized dog standing comfortably in the restraining apparatus. Typieal low voltage, fast frequency EEG activity was observed in areas 8, 1, dorsal hypothalamus, and midbrain reticular formation. The higher voltage aretivity of the medial amygdala and olfactory bulb consisted of periodic bursts which were synchronous with respiration. The loft hand portion of panel A illustrates the electrical activity during panting, while the right hand panel illustrates the electrical activity during normal respiration. As observed in other dogs as well the olfactory bursts tended to oceur primarily during inspiration, but were also seen in expiration. Following the administration of $1.0 \mathrm{mg} / \mathrm{kg}$. of morphine given intravenously considerable EEG slowing was present. Electrical activity in the olfartory bulb was decreased and paralleled a decrase in the depth of respiration. In the left hand portion of panel $B$, figure 6 , during panting there was a marked decrease in the amplitude of respiration and this was assoriated with minimal to no electrical bursts in the olfactory bulb and amygdala. Similar effects were observed during regular respiration which likewise was decreased in depth and rate by morphine. The animal alternated between periods of behavioral as well as EEG arousal and drowsiness. Any afferent stimnlation quickly cansed arousal but it appeared that the duration of arousal was shortened. The administration of $1.0 \mathrm{mg} / \mathrm{kg}$. of $\mathrm{n}$-allylnormorphine promptly reversed the gross behavioral and EEG effects of morphine. Characteristically the electrical burst activity of the olfactory bulb and amygdala were enhanced. $\Delta$ s illustrated in panel $\mathrm{C}$, figure 6,2 types of electrical bursts were present in the olfactory bulb as described previously. The $20 \mathrm{c} / \mathrm{sec}$. bursts were easily evident in the amygdala. Blockade of the ipsilateral nostril prevented the burst activity from appearing in both the amygdala and the olfactory bulb (see panel C, fig. 6). Opening the ipsilateral nostril promptly caused the electrical bursts to reappear. Occlusion of the contralateral nostril tended to enhance slightly the respiratory bursts.

\section{EEG Effects of Chlorpromazine.}

The effects of $1.0 \mathrm{mg} / \mathrm{kg}$. of chlorpromazine given intravenously were studied in 5 dogs. Characteristically, chlorpromazine caused the animals to become more quiet and drowsy. The EEG was accompanied by generalized slowing. Respiration was definitely reduced in frequency and depth. Similarly the electrical burst activity in the olfactory bulb and amygdala were depressed. Any afferent stimulation promptly caused arousal of the animal but the duration of behavioral as well as EEG arousal was reduced. Marked afferent stimuli, which eaused behavioral arousal, increased respiration and the electrical bursts became elearly evident. At times theseremed enhanced over the normal control burst activity. Such diphasie effects depending upon whether the animal was aroused or asleep wore also evident in the studies of chlorpromazine in the monkey. A total of 4 different monkeys were studied. Chlorpromazine had a marked tendeney to increase the alpha-like rhythm in the oceipital neocortical areas and to diminish slightly the amplitude of the respiratory bursts. However, when the animal was aroused the electrical burst activity appeared to be slightly enhanced over coutrols. In addition, there appeared to be a qualitative change in which more prominent 20 to 30 c sere. waves aceompanied the intervals between inspiation.

\section{EEG Effects of Alpha-Chloralose.}

The effects of 50 to $100 \mathrm{mg} / \mathrm{kg}$. of alphachloralose given intravenously were studied in a total of 5 dogs. Generally chloralose markedly altered the electrical activity of the brain producing eharacteristic high voltage, slow waves of approximately 3 to $6 \mathrm{c} / \mathrm{sec}$. Within 15 min. after the intravenous injection of $50 \mathrm{mg} / \mathrm{kg}$. of alpha-chloralose the dogs were unable to stand and showed generalized slow waves and depressed respiration. At this time no respiratory bursts were present in any of the rhinencephalic structures. Within $21 / 2$ hours the animals were able to stand up following afferent stimulation. 
Gradually the respiratory burst activity in the olfactory bulb returned toward control levels. Even 31/2 hours after administration of chloralose some EEG slowing and diminished burst activity were present, but EEG arousal was easily elicited. The duration of the EEG effects of chloralose was approximately 4 hours.

\section{DISCUSSION}

Electrical bursts of approximately 20 to $40 \mathrm{c} / \mathrm{sec}$. in rhinencephalic structures stich as the olfactory bulb, amygdala, pyriform and prepyriform cortex, and posterior hypothalamus of the dog and monkey appear to be due to the flow of air through the nostrils. Although the bursts are usually synchronous with respiration, they only occur when air flows through the nostril. Therefore, one does not always obtain perfect correlation with the respiratory rate, since sometimes the animal breathes through its mouth. This induced afferent activity appears to be primarily $\mathrm{mi}$ lateral. It is abolished by occlusion of the ipsilateral nostril or by spraying the nasal mucosa with a local anesthetic. Although such electrical activity was observed in monkeys when they were asleep. characteristically the bursts were most clearly evident when the animals were aroused. Various afferent stimuli capable of EEG and behavioral arousal increased the activity in the rhinencephalic structures. It seemed that the important factor was the degree of behavioral arousal. The more the animal was excited, the more likely bursts were observed. Generally, in the monkey the bursts were synchronous with inspiration. Similarly, in the dog bursts were ustally synchronous with inspiration but also were seen occasionally during expiration as well. In the monkey the frequency of the indnced alectrical activity was approximately $40 \mathrm{c} / \mathrm{sec}$. both in the olfactory striae, pyriform cortex, and the medial amygdala. Althongh the frequency of the bursts in the olfactory bulb of the dog were approximately $40 \mathrm{c} / \mathrm{sec}$, every second spike seemed somewhat enhanced. 'The basic frequency of the bursts in the medial amygdala and posterior hypothalamus were precisely half the frequency of the bursts in the olfactory bulb. In both species of animals the rhinencephalic bursts definitely seemed to be correlated with the degree of FE( arousal as described in cats by Lavin et al., 1959. Although the electrical bursts appeared at approximately the same rate as respiration these investigators felt that the phenomenon was dissociated at times from respiration. However, as seen in our studies it appears that the presence of the bursts is related to the flow of air through the nostril and not necessarily to thoracie or abdominal respiration. Lavin et al. felt that the burst phenomena represented a centrifuaral input into the olfactory bulb from the brainstem reticular formation as a result of EEG arousal. In dogs and monkeys this does not appear to be the explanation. However, before this point ran be arlefuately answered it will bre necessary to repeat the experiments following transestion of the olfactory tract.

Although our study does not support the (onclusions of Lavin el al. (1959) their hypothesis may still be quite valid. Most of the procedures that we have used for abolishing the bursts, such as occlusion of the ipsilateral nostril or spraying the mueosa with a local ancesthetic would tend to block afferent activity originating at the reseptor site. $\Lambda$ facilitatory centrifugal artivation of the olfaretory bulb during arousal may be a physiolocrical mechanism for enhancing the sensitivity of olfactory afferents. Certainly there is andomical evidence of some antrifugal fibers into the olfactory bulb. Recruiting waves have been recorded by Arduini and Moruzzi (1953) in the olfactory bulb of the at during low frequency electrical stimulation of the diffusely projecting thalamic nuclei. Kerr and Hagbarth (195.5) have shown that there is a suppression of olfactory activity following high frequency stimulation of various rhineneephalie structures.

The effects of drugs in modifying the eleetrical burst phenomenon paralleled their ability to produce gross behavioral and respiratory stimulation or depression. Amphetamine and trans- $\pi$-oxocamphor cansed a marked increase in the electrical bursts reaorded in the olfactory bulb and varions rhinencephalic structures. The effects of agents which produced gross depression of the animal 
produced a depression of the burst phenomenon. Thus morphine, chlorpromazine, and alpha-chloralose produced depression of this activity. This seemed to parallel the degree of gross behavioral and respiratory depression. The administration of n-allylnormorphine to animals previously given morphine "aused a marked antagonism of the gross behavioral and respiratory depression as well as a marked increase in the electrical bursts. Following afferent stimulation of any kind that caused gross behavioral arousal the animals had increased burst activity in their rhinencephalic structures. Occasionally, following the administration of chlorpromazine during the recovery period when the animals were rigorously aroused the electrical bursts "ven appeared enhanced over the pre-drug state. With respect to morphine, chlorpromazine and chloralose, the decrease in burst activity did seem to parallel the depression of respiration. Occasionally following morphine and ehloralose, vigorous afferent stimulation also produced enhanced burst activity. This sngeests that not all of the effects observer in the chronic dogs could be explained simply on the basis of ehanges in the state of respiration. Perhaps an additional factor within the brain itself was operative. Further resedreh along these lines is necessary. This "an be best accomplished in unanesthetized animals immobilized with various neuromusevlar blocking agents and placed on artificial respiration since it is extremely important to control the amount of air flow throngh the mostril to test the effects of drugs.

If it is agreed that the burst phenomenon in rhinencephalic structures is the result of primarily an olfactory input it is necessary to explain why room air can elicit this phenomenon since accommodation to odors in the enviromment would readily take place. Adrian (1942) first suggested that air flow could alieit discharges in the olfactory bulb due to a merhanical receptor. However, he subsequently rejected this notion on the basis that in his early experiments the air was contaminated with odors (Adrian 1950b). Rerently, Teki and Domino (1959), have gathered evidence for the presence of a mechanical receptor in olfactory function. Pre- sumably such a mechanical receptor that responds to the flow of air or to dynamic. changes in pressure is the peripheral end organ within the nostril responsible for the burst phenomenon.

\section{SUMMARY}

Electrical bursts of approximately 20 to $40 \mathrm{c} / \mathrm{sec}$. were observed in some rhinence phalic areas including the olfactory bulb, olfactory stria, pyriform and prepyriform cortex, and the medial amygdala of the dog and the monkey with chronically implanted electrodes. The amplitude of the electrical bursts depended upon the degree of gross behavioral arousal and respiratory stimulation. The more aroused and exeited the animal the greater was the amplitude and frequency of the reetrical activity. These bursts were of a spindling character and appeared to be due to the flow of air throngh the ipsilateral nostril. They could be abolished by occlusion of the ipsilateral nostril or by spraying the nasal mucosa with a local anesthetic solution.

Various drugs that modified the state of arousal and respiration modified the electrical bursts; d-Amphetamine and trans- $\pi$-oxoramphor markedly inereased the electrical burst activity while morphine, ehlorpromazine, and alpha-chloralose depressed this activity. Most but not all of the effects observed were rolated to the degree of respiratory stimulation or depression.

\section{RÉSIMÉ}

Des bouffées d'activité électrique d'environ 20 à 40 cycles par seconde ont été enregistrées au moyen d'électrodes implantées chroniquement dans certaines régions rhinencéphaliques incluant le bulbe olfactif, les stries olfactives, le cortex pyriforme ot prépyriforme, et le noyau amygdalien médian, chez le chien et le singe. L'amplitudi des bouffées dépendait du degré d'état de vigilance et de la stimulation respiratoire. I'amplitude et la fréquence de l'activité électrique étaient d'autant plus grandes que l'animal était plus éveillé et plus excité. Ces bouffées avaient caractère de fuseanx et semblaient dues au courant d'air dans la narine ipsilatérale. Elles ponvaient être abolies par l'oc- 
clusion de la narine ipsilatérale ou par une anesthésie locale de la muqueuse nasale.

Divers médicaments modifiant l'état d'éveil et la respiration, changeaient les bouffées électriques. L'amphétamine et le transoxocamphre augmentaient considérablement les bouffées électriques alors que la morphine, le chlorpromazine et l'alpha chloralose déprimaient cette activité. Isa plupart sinon tous ces effets observés étaient fonction du degré de stimulation ou de dépression respiratoire.

\section{ZISAMMENFASSUNG}

Elektrische Entladungsgruppen ron etwa 20) bis $40 \mathrm{~Hz}$ wurden an einigen Stellen des Riechhirns bei Hunden und Affen mit dauerimplantierten Elektroden beobachtet. Es handelte sich nm den bulbus olfactorius, die stria olfactoria, den pyriformen und praepyriformen Cortex und die medialen Anteile der Amygdala. Die Amplitude der Entladungsgruppen hing ab vom Grad der im Verhalten sichtbaren Erregung (behavioral arousal) und der respiratorisehen Stimulation. Je erregter das Tier war, umso grösser waren Amplitude und Frequenz der elektrischen Aktivität. Diese Entladungsgruppen waren spindelförmig und sehienen durch den Luftstrom der gleichseitigen Nasenöffunng verursacht zu sein. Sie konten zum Verschwinden gebracht werden durch Verschluss der gleichseitigen Nasenöffuung oder durch Besprayen der Nasenschleimhant mit einem Lokalanaesthetikum.

Verschiedene Drocen, welche Einfluss anf den Erregungszustand und auf die Atmung hatten, modifizierten die elektrischen Phänomene. Dextroamphetamin und trans- $\pi$-oxo- kampfer verstärkten die alektrische Entladungsgruppen-Tätigkeit, während Morphin, Chlorpromazin und alpha-Chloralose sie verminderten. Die meisten, aber nicht alle, der beobachteten Effekte standen in Bezichung zu dem Grad der Atmungr,-Stimulation oderDepression.

\section{REFERENCES}

ADRlan, E. I). Olfactory reactions in the brain of the hedgehog. I. Phyciol., 1942, In): 459-473.

ADRIAN, E. I). The electrical activity of the mammalian olfactory bull. EEG Clin. Nonrophysiol., 1950it, ?: $377-388$.

Adras, F. F. Olfaction discrimination. Ann. Psy chol. 1950b, 50: $107-113$.

Arpelise, A. and Monuzzi, G. Sensory and thalamie sychronization in the olfactory billh. EEG Gin. Neurophysiol., 1953, 5: 235-240.

Domino, E. F. A phamacological analysis of the functional relationship hetween the brain stem arousal and diffuse thalamic projection systroms. I. Tharmacol. Exper. Thrrap., 1955, 115: 449-463.

KerR, J). I. B. and HAgBarTh, K. F. An investiga tion of olfactory centrifugal fiber system. I. Neurophysiol., 1955, 18: $362-374$.

IAVIN, A., AlCOChR-CUARó, C. hur HernándezPEón, R. Centrifugal arousal in the olfactory bulls. Science, 1959, 199: 332-333.

Madifin, P. D. and DELgado, J. M. R. Filectrieal and chemical stimulation of fromtotemporal por tion of limbic system in the waking animal. EEG Clin. Niurophysiol., 1953, ,5: 91-10u.

Novikova, T. A. and Krvorks, (: T. Electrophysiological study of the olfactory analyzer. Fiziologischeshit Zhornal ZSSR, Inemi I. M. Sechenoma, (Moskova), 1953, 39: 35-46.

OrszeWski, J. The Thalamm of the Macaca Mulatia. Basel, S. Karger, 1952, 93 pp.

Riler, J. A. A simple method for weliling thermocouples. sicience, 1949, 109: 281.

RoITbik, A. I. and Kufchinashula, S. $N$. "Electrical activity of the mammalian olfactory bulb", Fiziologischeskii Zhurnal USSR Ineni $I$. M. Sechenoma, (Moskova), 1952, 98: 350-355.

TFKI, S. and Domino, E. F. Some evidenee for a mechanieal receptor in olfactory function. Fed. Proc., 1959, 18: 454 .

Reference: Domino, F. F. and UEKI, S. An analysis of the electrical burst phenomenon in some rhinencephalic structures of the $\operatorname{dog}$ and monkey. EEG Clin. Neurophysiol., 1960, 12: 635-648. 